\title{
The EU's Socioeconomic Governance 10 Years after the Crisis: Muddling through and the Revolt against Austerity
}

\author{
AMANDINE CRESPY (D) \\ CEVIPOL/Institut d'Etudes Européennes, Université libre de Bruxelles, Brussels
}

\section{Introduction}

Over ten years ago, at the end of 2009, Greece entered one of the most tumultuous periods in its contemporary history, and the entire Economic and Monetary Union (EMU) founded in 1992 threatened to collapse under the effects of the global financial crisis and the poor capacity of European governing elites to find rapid appropriate responses. After an initial Keynesian moment, 'austeritarianism' emerged from intergovernmental summits, with the Eurogroup, the informal gathering of the finance ministers of member states, with no legal existence in the EU's treaties, having the upper hand on decisionmaking. The strategy then embraced was one of internal devaluation in indebted countries, limited financial support by creditor members of the EMU conditional upon social retrenchment, and a collective commitment to stringent fiscal discipline. More than the financial crisis itself, it was the political response to it, guided by a questionable belief in expansionary fiscal consolidation (Blyth, 2013, pp. 212-16), which left EU countries struggling with a long recession. Ten years on, have Europeans recovered from the crisis? And where has the strategy of muddling through left the EU?

Before the outbreak of the coronavirus pandemic, decision-makers' discourse emphasized that the crisis was over. Not only had the EU's average growth rate stabilized at around 2 per cent, but the average unemployment rate in the EU had come down from 10.5 per cent in 2013 to 6.4 per cent in 2019. Yet the Euro crisis was never a pivotal moment bringing about a full recognition of the failure of financial capitalism and paradigmatic change. Instead, the meltdown of the banking system stumbling over excessive (private) debt eventually resulted in the remarkable resilience of neoliberalism (Crouch, 2011; Schmidt and Thatcher, 2013) which led to an acceleration of pre-existing trends, for instance, the 'infrastructural power' of financial markets over monetary policy (Braun, 2018) and the subordination of social policy to the economic imperatives of competitiveness and fiscal discipline (Crespy and Menz, 2015). In a world where politicians speak to the markets as much as they speak to the people (Schmidt, 2014), the prevailing discourse had been that 'there is no alternative' to prioritizing responsibility towards creditors over responsiveness to voters (Mair, 2013).

When the pandemic hit and confinement put economies to a halt in the spring of 2020 , Europeans had been muddling through the recession for a decade. None of the structural issues affecting the socioeconomic governance of the EU had been adequately addressed. What is more, it is argued, the way the crisis was handled only exacerbated the loss of trust in political institutions and the revolt against governing elites. The first section of this article shows how the austeritarian response to the financial and debt crisis have left enduring marks on the EU as a union of peoples and states, despite a sensible inflection in 
policy-making away from austerity. The second section discusses the political deadlock that characterizes debates over EMU reforms, in particular, over needs for stabilization and democratization. The third section explains how the perceived lack of social justice in Europe feeds into social and political polarization, resulting in the strengthening of populist political forces.

\section{The Enduring Legacy of Europe's Great Recession}

The recession ensuing from the 2008 financial crisis unveiled the fragility of Europe's socio-economic foundations in two respects. On one hand, it accelerated the forms of social and territorial inequality resulting from the financialisation of the Europeans economies. On the other, it laid bare how the EU was struggling politically to depart from the structural ordo-liberal bias of its governance and proved little to manage socio-economic interdependencies in a timely and effective fashion.

\section{A Divided Union of Peoples and States}

A first way to look at the legacy of the crisis is to examine how it has affected levels of inequality in European societies. In this regard, rising levels of GDP per capita or declining levels of poverty hide a much more complex reality. Across Europe, the average share of national income captured by the top 10 per cent of earners has been on the rise since 1980, ranging from approximately 29 per cent in northern Europe to 32.5 per cent in western Europe in 2017 (Blanchet et al., 2019). However, it is possible to discern that the Euro crisis has aggravated the rise of inequality. First, the crisis put a halt to the fall in the poverty that Europe had experienced since 2000, stabilizing at around 21 per cent of people at risk of poverty (that is, with an income under 60 per cent of the median income nationally). ${ }^{\prime}$ Behind the various fiscal and social systems to correct for inequality, some common trends can be identified. According to an Organization for Economic Cooperation and Development study, the improvement in average household disposable incomes in the recovery from the recession hides important disparities. In the vast majority of EU countries, the disposable income of the top 10 per cent of earners has grown much faster than that of the bottom 10 per cent (Organization for Economic Cooperation and Development, 2017). We also know that changes in disposable income depend on the structural evolution in labour markets. Flexibilization and the rise of precarious, part-time jobs have clearly affected income levels, with women being more affected than men; thus feeding into the gender pay gap. Meanwhile, rampant in-work poverty has become a reality across the board and has continued to rise from 8.9 per cent in 2012 to 9.6 per cent in $2018 .{ }^{2}$

Incomes are only part of the story, however. Looking at net wealth, including property, helps us to draw a more accurate picture. Strikingly, the decrease of median net wealth between 2010 and 2014 has been almost thrice less important for the top 10 per cent of earners $(8.7$ per cent) than for the bottom 10 per cent of earners across euro area countries (Sweeney and Wilson, 2018). Net wealth is also affected by the ability of welfare states to deliver services (such as childcare or health care) at affordable prices. Driven by the

\footnotetext{
${ }^{1}$ All figures are from Eurostat: www.ec.europa.eu/eurostat

${ }^{2}$ All figures are from Eurostat: www.ec.europa.eu/eurostat 
objective of decreasing public expenditure, austerity packages systematically targeted public services in a way that has affected the welfare of those who cannot afford private services (Crespy, 2016, pp. 189-227).

The great recession has also exacerbated inequality between European societies. In some parts of Europe the absence of prospects has translated into a demographic haemorrhage, especially among qualified young people, to EU countries with more dynamic labour markets. Spain, Portugal, Latvia, Lithuania or Romania - to name a few - have been badly affected by the brain drain. At a macro level, the Euro crisis revealed that the socio-economic convergence the founders of the EMU had hoped for had not taken place. Structural disparities have proved enduring and there is a persisting gap in socioeconomic development between a core of rich northern and continental European countries and the southern and eastern peripheries (Makszin et al., 2020). While GDP per capita remains higher in the south than in the east (about 45 per cent compared with approximately 30 per cent of that of the core), countries of the eastern periphery have remained on an ascending GDP trajectory throughout the recession. In contrast, southern Europe has experienced an important decline, which came to a halt only in 2016.

Politically, too, the Euro crisis has divided the continent, creating asymmetric power relations between creditors and debtors. The confrontations between Merkel's Germany and the Syriza government over bailouts and conditionality triggered unprecedented and shocking expressions of mutual hate, ranging from misplaced moral judgements to clichés and featuring images of Angela Merkel as a Nazi. Rather than recognizing the Euro area's systemic problems, the prevailing diagnosis of the crisis was essentially framed as a tale of 'Northern saints and Southern sinners' (Matthijs and MacNamara, 2015). Although the political climate seems to have eased over the past years, EU politics are shaped by a powerful 'Hanseatic league' of hawkish creditor states up to the present (Schild and Howarth, 2020). Clearly, a sense of mutual trust and recognition has been lost as a result of the financial crisis. Although the rate of unemployment has decreased on average since 2012, an entire generation of young people still experiences hardship, with youth unemployment ranging from 20 to 40 per cent in seven EU member states, including southern countries plus Croatia and France. Against this background, socioeconomic governance in the EU was one of mixed signals in terms of the social effects of the recession.

\section{The Sluggish Shift of EU Governance Away from Austerity}

Ten years after the Euro crisis broke out, it has been widely recognized that the EU's focus on adjustment by deflation and fiscal discipline has been to a large extent self-defeating. In 2013 the International Monetary Fund was first to criticize the EU's obsession with fiscal discipline. From 2014 onwards the Commission headed by Juncker initiated a shift away from austerity. When the new Commission president, Ursula von der Leyen, took over in November 2019, departing from muddling through and giving the EU a new political impetus appeared as the most pressing tasks.

From 2011 onwards, the European semester was set up as a broad governance framework encompassing the surveillance of budgets, with a legal hardening of the rules attached to the stability and growth pact, economic surveillance through the macro-economic imbalance procedure, and a soft coordination of social policies, that 
previously occurred through the social open method of coordination. After the initial phase that had clearly focused on austerity and fiscal consolidation under Barroso, the Juncker Commission partly acknowledged the need for a trade-off between fiscal consolidation and governments' capacity to enforce structural reforms that would generate growth in the medium term, and subsequently relaxed the former and stressed the latter. A number of initiatives have aimed to stimulate growth and tackle social issues. As Commissioner for Employment and Social Affairs under Barroso, Laszlo Andor was active in promoting a more social agenda by promoting, for example,the social investment package in 2013 and the youth guarantee in 2014. Relying partly on soft law and a mix of national and EU resources (from the European social fund), both instruments were meant to tackle the two main problems brought about by the crisis; namely skyrocketing youth unemployment and the debasing of public services. While these initiatives are to be welcome, they both exhibit the inadequate level of resources set aside to tackle the sheer size of the problems. The European-wide agenda for social investment, in particular, has been left to a large extent to the traditions, willingness and fiscal means of national governments.

At the same time, Juncker Commission operated a, important discursive turn towards investment. And the 'Juncker plan' (now rebranded InvestEU) was launched in 2015 as the Commission's flagship initiative to leverage private investment across Europe. Besides the plan's lack of capacity to boost growth on a large scale, an independent report from 2019 points to issues regarding the green earmarking of investments, the geographical coverage by the elected projects, and governance, transparency. It points, for instance, to the 'aggressive promotion and incentivization of PPPs for social and economic infrastructure financing (...), especially in sensitive public services sectors' (Network/ Counterbalance, 2019). In 2018, public investment in the EMU's southern periphery had clearly not yet recovered, stagnating at its 2012 level after a dramatic decrease in 2009 (Seikel and Truger, 2019). The main initiative of the Juncker Commission has been the proclamation, in 2017, of the European pillar of social rights, a catalogue of 20 principles for ensuring decent life and work and to be enforced through a combination of soft law (recommendations) and hard law (new regulations). One of the main pieces of legislation so far has been the work-life balance directive in 2019. This relatively ambitious Commission proposal (creating a right to paternity leave or to carers' leave) has been largely watered down by the Council by leaving the practicalities (especially the levels of compensation offered) to member states. On the soft law front, the Commission is pushing for the creation of a child guarantee to tackle child poverty through a consultative process on the feasibility thereof conducted in 2019. Finally, when von der Leyen took office in November 2019 she committed the Commission to take action to ensure that a satisfactory proportion of European workers enjoy a fair minimum wage. As consultation of the social partners is still in process at the time of writing, it is not clear that the Commission will find sufficient political support (and a relevant legal basis) to adopt a binding instrument on this issue. Overall, the vast majority of social rights entailed in the pillar (notably related to work), are merely to be monitored through the European semester.

The European semester (also called new economic governance) serves to perform the multilateral monitoring of member states' fiscal, economic and social policy over a yearly cycle, steered by the Commission. This broad governance framework set up in 2011 encompasses stringent regulation of the stability and growth pact adopted in 2011-12 as well as the soft coordination of social policy (the 'Europe 2020' strategy) that formerly 
occurred via the open method of coordination. The literature dealing with the EU's new economic governance displays contrasting assessments of its nature and effects. Overall, a partial 'socialization' of the European semester has been detected (Zeitlin and Vanhercke, 2017). There has been a growing concern for social issues in the substantial messages sent by the Commission through its annual growth surveys and the country-specific recommendations. New instruments have been integrated to ensure the closer surveillance of social issues in the member states, as social and employment actors in the Council and Commission have fought back to extend their role in the process. Yet by adopting these strategies socially minded actors have had to moderate their ambitions (Copeland and Daly, 2018). Furthermore, a closer look at the substantial meaning and content of these recommendations in the realm of social policy provides two insights (Crespy and Vanheuverzwijn, 2017). First, the European semester has long remained focused on a typical neoliberal agenda centred on the liberalization of products and services markets, the deregulation of labour markets, and the reform of public administration. At the same time, structural reforms have from the outset encompassed calls for social investment as well as measures requiring retrenchment of social benefits. Thus, governments have found themselves facing contradictory injunctions to save (fiscal discipline) and to spend (social investment). A main policy outcome of the semester has been the implementation of labour market reforms which, overall, have 'operated mainly through the reduction of security for insiders, not by increasing job security for outsiders' (Arpe et al., 2015, p. 50). From a critical perspective, thus, the fuzzy notion of structural reforms has allowed EU institutions to address these criticisms to some extent.

Against this background, the semester cycles of 2019 and 2020 clearly show a greater concern for fostering social investment and tackling exclusion and inequalities. As the consequences of the pandemic will exacerbate the need for effective social responses, political agreement over some fundamental underlying issues has so far proved elusive.

\section{The Pending Agenda for A More Social and Democratic EMU}

Shortly after Macron was elected as French president in 2017, he put forward an agenda for far-reaching reforms in the EU in a grand speech at Sorbonne University, calling for a 'sovereign, united and democratic Europe'. One of his proposals emphasized the need for new instruments to ensure stability and convergence in the Euro area, notably through a common budget based on new EU resources (among others). This was linked to a more integrated governance, featuring a common minister, greater control of the European parliament (EP), and social measures to fight against social dumping (a revision of regulations on the posting of workers and new rules guaranteeing minimum wages). Macron put these proposals at the centre of the Franco-German agenda, a discussion that rapidly got bogged down between reluctance and delays. It eventually became clear that the expected major overhaul of the EMU was not to take place, leaving the two main issues unsettled: stabilization and democratization.

\section{Stabilization}

Stabilization refers to the ability of the Euro area to cope with forthcoming external shocks such as financial crises or unexpected events (like a global pandemic) that may disturb European economies and trigger a new recession. Ten years on from the subprime 
crisis, is the eurozone fit to meet the next crisis? This debate took shape around essentially two policy ideas: the establishment of a European unemployment reinsurance fund and the creation of a eurozone budget.

The underlying idea of the first proposal was to compensate for the social costs of adjustment in the event of shocks in more vulnerable economies that are competing against more stable ones within a monetary union. Stabilization would therefore be facilitated by a form of automatic stabilizers such as a European unemployment benefits scheme. This idea has been long discussed, culminating in 2016, when high-ranking politicians and economists, including Marianne Thyssen, Pierre Moscovici, Pier Carlo Padoan, Sebastian Dullien and Paul De Grauwe, gathered together at the Centre for European Policy Studies to discuss alternative designs. The preferred option does not involve direct transfers from the EU to unemployed individuals. Rather, states would contribute to an insurance fund, which could be accessed by those countries most affected by external shocks and flow into national schemes (Andor, 2017). Even though the idea was mentioned in the 2018 Franco-German roadmap for the Euro area, it has not yet materialized as an EU policy.

These questions have generated fascinating academic debates about the normative underpinnings of EMU and the extent to which Europeans should be bound by financial and social solidarity. Drawing from Weber, Ferrera (2017) suggested, for instance, that the EU could be conceived as a neighbourhood community, underpinned not by mere altruism but by reciprocity and beneficence: a form of basic compassion taming economically motivated behaviour. Others have stressed that the EU should above all guarantee non-domination of some states over others and compensate for the unequal benefits stemming from integration due to the diversity of national social systems and their unequal capacity to adapt to economic and fiscal competition (Sangiovanni, 2013). On the political front, however, debates have revolved around the dichotomy between risk reduction and risk sharing. Here the concept of moral hazard has been key (Vandenbroucke et al., 2016, pp. 9-11; Pierret, 2019), suggesting that sharing the financial burden of debt and recessions would act as a deterrent for less competitive member states to adopt sound policies for reducing debt and enforcing structural reforms. Thus, creditor countries put forward their concern that sharing risks through new financial instruments would de facto entail permanent financial transfers, hence advocating the reduction of risk through 'responsible' policies. In the same way that they had obliterated discussions around the creation of eurobonds in 2008-10, these underlying normative positions impeded decisions about a possible unemployment reinsurance fund or a eurozone budget.

After lengthy discussions and much resistance from a group of creditor states (especially the Netherlands, Finland, Ireland, Latvia and Lithuania), Macron's grand proposals for a eurozone budget resulted in 2018-19 in an agreement on a 'budgetary instrument for convergence and competitiveness' (BICC). The instrument, endowed with about 17 billion euro $^{3}$ from the EU budget, is to be distributed to member states on the basis of projects to 'finance packages of structural reforms and public investments' (Council of the EU, 2019). All commentators noted that the BICC fell far short of what could be regarded as a eurozone budget. Many economists have reckoned that the BICC was a first, albeit marginal step in the right direction, possibly 'leaving the door open for a

\footnotetext{
${ }^{3}$ The final amount dedicated to the BICC will be determined in the negotiations about the EU's multi-annual financial framework.
} 
more meaningful instrument in the future' (Goncalves Raposo, 2019). But they have also stressed that the sheer size of the sum proposed (about 0.01 per cent of the eurozone's GDP) could under no circumstances perform a stabilization function. More strikingly, there is ambiguity as to the very objectives of the instrument for it to please both those who want to use it as a tool for boosting investment and convergence, and those who see it as a means to promote competitiveness through structural reforms. To conclude, rather than stabilization (let alone solidarity), it seems that the $\mathrm{OHIO}$ doctrine, according to which governments should put your 'Own House In Order' first, is still the game in town. It is now uncertain how the BICC will fare in the reconfiguration of EU resources aiming at fighting the consequences of the Covid-19 pandemic.

\section{Democratization}

The shake-up of the Euro area as a result for the financial and debt crisis triggered a debate about its incomplete, undemocratic governance. The key role of the European Council, and even more that of the Eurogroup, in particular, has raised questions as to the accountability of those deciding on issues that touch upon fiscal policy, the welfare state and budgets, all of which are the prerogatives of sovereign states and parliaments. In the 2015 'Five Presidents Report', key EU politicians advocated increasing EP control over the EMU. In academia, much more radical ideas were put forward. A group of French scholars (including Thomas Piketty) suggested the creation of a second assembly, made up of national MPs, which would decide on all the important socioeconomic matters in the Euro area, including the policy of the European Central Bank (Hennette et al., 2017). This institutional innovation, despite its cost, was, in their view, essential for reconnecting EMU governance to domestic political arenas and provide the necessary democratic legitimacy. Comparing the Bank of England, the US Federal Reserve Bank and the ECB, other scholars have shed light on the negative impact of central banking on inequalities, notably due to their embeddedness with financial markets. For this reason, they question the dogma of central bank independence.

In the political arena, Macron's proposals were were not as radical and, although they included the idea of increased control by the EP, greater emphasis was put on creating a post for a common finance minister, an idea echoing the long-standing French plea for a 'gouvernement économique' in the EU. However, strengthening the executive without matching it with parliamentary control would have been very questionable from a democratic point of view. In any event, discussions on eurozone reforms never seriously addressed democratization concerns. Instead, attention focused on improving the functioning of the European semester. When the Juncker Commission undertook a 'revamp of the European Semester' in October 2015, it called for enhancing the ownership of the EU's socioeconomic governance, meaning that the semester would be better endorsed and implemented if social partners and national parliaments, in particular, were better aware of the semester and able to feed into its objectives. Despite these good intentions, the semester has remained, to a large extent, a bureaucratic exercise serving to consolidate a European administrative space (through intense dialogue between the Commission and national administrations) but with little salience in national political arenas (Vanheuverzwijn and Crespy, 2018; Papadopoulos and Piattoni, 2019). Hence, overall the EMU remains distanced from the democratic credentials one would wish for 
in a policy area that shapes economic life, from banking activities to labour markets and welfare states.

\section{III. 'The People' against Technocratic Governance}

In the aftermath of the financial and debt crisis, the EU's political strategy of muddling through has been accompanied by the aggravation of long term social transformations. These have powerfully reshaped national party landscapes and boosted contestation against the kind of modernization project embodied by the EU.

\section{From Social Polarization to Popular Revolts}

One of the first effects of the great recession was to accentuate contemporary sociological cleavages on social mobilization on EU-related matters. Contemporary European societies find themselves divided around a new social line which opposes, roughly speaking, the winners and the losers of globalization and Europeanization (Kriesi et al., 2008). While it is linked to contemporary forms of economic and social transformation, this new cleavage partly overlaps with older ones. The winners are typically urban professionals with a strong educational background and post-materialist values, while the losers tend to live in rural or deindustrialized areas and be more prone than winners to see immigrants and social diversity as a cultural and economic threat.

Against this background of structural transformations, the 2008 financial crisis and its aftermath have triggered a new cycle of protest and anti-austerity social movements (Della Porta, 2015). While activists of the Global Justice Movement, which had its heyday in the 2000s, belonged mainly to the educated middle class, anti-austerity protesters have more diverse profiles, including precarious or poor workers, unemployed people, people from rural areas, or students. While all criticize the effects of inegalitarian capitalism and the failure of representative democracy to serve the masses, they have also sometimes articulated contradicting demands. This has made it difficult for political actors wishing to capitalize on popular revolt to articulate coherent policy programmes or ideologies that could be backed by a majority.

The Yellow Vests (gilets jaunes) movement, which almost paralysed France from autumn 2018 and until the end of spring 2019, illustrates this cleavage best. Starting with a protest against new taxes on fuel, the movement's grievances rapidly enlarged to include a broad 'reformulation of the social question' around the issue of tax justice (Piketty, 2018; Spire, 2019) primarily by the citizens of the lower middle class, directing the revolt around precarity of work combined with unbearable fiscal burdens. The anger expressed by the movement focused mostly on Macron, who was accused of being the 'president of the rich' after decreasing taxes on the wealthiest citizens and on revenue from the capital. At the same time, the movement was criticized by many opinion leaders and by part of the public opinion for its excessive brutality and acts of vandalism, the incoherence of its demands, and its xenophobic and anti-Semitic flavour, as it was progressively infiltrated and captured by far-right forces.

While some parallels were made between the gilets jaunes and the sans-culottes of the French revolution, lessons can be drawn in terms of the two main challenges facing citizens and decision-makers alike. First, the mobilization of the gilets jaunes was 
successful in externalizing a pervasive and deep anger among the population. However, the diversity of backgrounds, views and demands impeded the emergence of spokespeople to represent the movement as a whole, to articulate coherent demands and to talk to decision-makers. The movement failed to unify its diverse consituent factions and faced much internal criticism. Ingrid Levasseur, a young nurse who had become a figurehead of the movement, failed to launch representatives for the European election and left the political scene in March 2019. Eventually, the division of the movement's representatives into three different lists (all receiving below 1 per cent of the vote) reflected the movement's inability to generate effective action in the political arena. Without the Yellow Vests' claims being adequately considered by established political actors, the motives of their revolt remained fundamentally unaddressed. The second lesson relates to the nature of these claims for social mobilization, considering that the movement was triggered by the rise of the tax on fuel. The 'social question' nowadays can only be conceived in terms of its articulation with the ecological transition and fiscal reforms. In this new context, fiscal policy has become the main instrument to ensure that the burden of the ecological adjustment will not only be borne only by the weaker members of society, leaving interests of powerful economic actors unaffected.

\section{Inclusionary Populism Giving Way to Exclusionary Populism?}

In 2000, prominent political scientists questioned how, notwithstanding dynamic eurosceptic parties, EU integration could profoundly alter the historically entrenched political cleavages in Europe, especially the left-right cleavage (Mair, 2000; Harmsen, 2005). The decade inaugurated by the financial crisis, however, has catalysed the transformations at stake, leading to the unimaginable remodelling of party systems in many EU member states. First, the EU has come to embody the values of cosmopolitan upper-middle class and elites, grounded on economic and political liberalism, while less affluent citizens have increasingly rejected it as a remote, faceless and undemocratic technocracy ruling from Brussels to serve the interests of the large corporations that lobby it. This change in political systems took various forms across different countries, shaped by historical legacies and institutional constraints and led by diverse emerging political actors. However, the most common development across countries was the new populist cleavage that has cut across the old left-right patterns, upsetting government and opposition dynamics and leading to political fragmentation and government crises in many countries.

From the outset of the recession, southern Europe has been a special place for observing the populist wave. The electoral rise of Syriza in Greece, Podemos in Spain and the Movimento Cinque Stelle (M5S) in Italy followed the social effects of the recession and austerity, as can be measured, for instance, by the decline of the social justice index in these countries (Kotroyannos et al., 2018 , p.6). Despite national and cultural differences, all three parties exhibited similarities in their discourse, with their harsh critique of domestic and European political establishments, and the broad opposition between an indefinite mass of 'the people' against the elites. They can be defined as 'inclusionary' populist parties, stressing the need to enhance popular democratic participation and to give disadvantaged groups a voice; in contrary to 'exclusionary' populism focusing on anti-immigration and nationalism, and distributional and cultural exclusion by those entitled to be part of 'the people' (Mudde and Kaltwasser, 2013; Font et al., 2019). 
Following recent electoral developments, we are arguably witnessing the end of an anti-austerity protest cycle which gave rise to inclusionary populism in southern Europe. Its strongest example, Syriza, which had governed Greece since 2015, handed power back to Greece's traditional right-wing New Democracy after losing the last Greek general election in July 2019. For some voters, Tsipras was seen to have betrayed socialist ideals whereas, for others, he was a victim of the ineluctable EU political diktat; and evidence that there is indeed no alternative to the neoliberal centrist mainstream in the current EU politico-economic order. In Italy M5S topped the polls with 32.7 per cent of the votes in the 2018 election and formed a coalition with the far-right Lega Nord. The unprecedented coalition of two populist parties called for an end to austerity and clashed loudly with the Commission over Italy's budget, forecasted to have a deficit over the 3 per cent threshold of the stability and growth pact. Nonetheless, due to many disagreements over a range of policies, the coalition was short-lived. Lega leader Salvini decided to withdraw his support strategically, hoping to rise to power. Yet MS5 then sided with the centre-left Partito Democratico to form a new coalition instead of calling an election. Meanwhile, the EP elections in May 2019 showed that the respective levels of support for the Lega and the M5S had reversed, with the latter halving its vote share to 17 per cent, while the former doubled it to 34 per cent. In Spain, Podemos (now under the coalition Unitas Podemos) experienced a stark decline from 21.15 per cent in 2016 to 12.9 per cent of the votes in November 2019. After repeated failed negotiations, Podemos eventually propped up a government coalition under Pedro Sanchez's Social Party. Meanwhile, the most notable result of this election was the rise of far-right Vox, which doubled its number of seats from 24 to 52 - compared with the earlier election in April 2019.

On the flipside, looking at the rise of exclusionary populism in the aftermath of the crisis, it is worth highlighting the resurrection of the long moribund far-right in Germany. The trajectory of Alternative für Deutschland (AfD) is interesting because it shows how initial contestation of the EMU can end up against EU socioeconomic governance can end up catalysing exclusionary populism. Founded as a single-issue party by a small group of anti-Euro academics, AfD changed leadership rapidly and transformed itsef into a classic anti-immigration party (Schmitt-Beck, 2017). This strategy was very successful, as we can see fromt AfD's electoral success, which within 4 years from its foundation became the third largest party in the 2017 general election (12.64 per cent of the votes). In the regional elections of 2019 it came second in the parliaments of Thuringia, Brandenburg and Saxony (with 23.4, 23.5 and 27.5 per cent of the votes, respectively). The rise of AfD has undeniably destabilized German politics by profoundly altering the available combinations for government coalitions, as the recent controversial political alliance between the Christian Democratic Union and AfD in Thuringia has shown. The German postwar political model and the normative grounds on which it was built have ended, which, in the medium run, could have implications beyond Germany.

To conclude, exclusionary populism focusing on racist anti-immigration discourses prevailed over inclusionary anti-austerity forms of populism, as the 2019 EP election showed. While the far-right non-affiliated sovereigntists and moderate eurosceptics gained 27 seats (compared to 2014), the European United Left/Nordic Green Alliance lost 14. With 207 seats out of 751, far-right populists are now in a position to wield significant leverage on the EU's political agenda, especially by blocking progressive socioeconomic agendas for a fair green transition, or institutional reform seeking to democratize the 
Union. This is likely to happen, as they are likely to find allies among some radicalizing conservatives of the European People's Party.

\section{Conclusion}

This article aimed to review the important developments in the EU's socioeconomic governance in 2019, taking stock of where we stand ten years after the global financial crisis destabilized the European banking sector and, eventually, the eurozone as a whole. A number of arguments have been discussed, emanating from intense scholarly research and debates in political science. First, the Euro crisis was never a critical juncture bringing about a paradigmatic shift in the EU's socioeconomic governance. Rather, it has accelerated the reinforcement of existing structural features, especially by hardening fiscal discipline and subordinating social objectives to the imperatives of competitiveness. Second, ten years on, despite a seeming recovery, the austeritarian response to the crisis has left a legacy of increased social inequality, accentuating the divide between the wealthy core and the peripheries of Europe. Third, the EU's socioeconomic governance has been a battlefield for political forces pulling in different directions with social issues becoming increasingly salient over time. Fourth, the overdue far-reaching reforms for ensuring stabilization and democratization of the EMU have ended in a political deadlock. Fifth, while the EU seemed paralyzed, domestic political arenas have been profoundly reshaped by popular movements and the rise of populist parties (left and right). Yet ten years on from the crisis, exclusionary forms of populism have grown stronger than the more inclusionary movements across the EU.

Now the Covid-19 pandemic in 2020 has suddenly upset the constellation inherited from ten years of muddling through. The pandemic has starkly revealed the consequences of chronic underinvestment in health care as well as the limitations of fiscal discipline. Thus, the pandemic cannot be regarded as a fully symmetrical shock, as some countries (especially Italy and Spain) have experienced more significant infection rates and have very limited fiscal capacities and feeble economies to meet the challenge. In the face of this new driver of inequality within and between European societies, EU leaders have decided to suspend rules for fiscal discipline and discussions for a significant financial package for fighting the consequences of the pandemic are in process at the time of writing. To what extent decision-makers will fully be able to draw the lessons from the past nevertheless remains an open question.

Ultimately, Europeans face two main challenges when shaping 'the world after Covid-19' in a progressive - as opposed to socially regressive - fashion. The way they do so will be reflected in the reshuffling of the EU's multi-annual financial framework for 2021-7. The first challenge is to overcome misconceived beliefs about moral hazard and unlock the confrontation between debtor and creditor states. What is at stake is the capacity to garner the resources needed to ensure the resilience of economies and green and social - investment. Their reflections should not only concern redistribution among member states but also put forward novel ideas about the EU's own resources (that is, the possibility of new European taxes). Second, fighting the consequences of the pandemic will have to be wisely articulated with the pre-existing agenda for a green deal promoted by the von der Leyen commission, which includes an important social policy component. Beyond the European Commission, a lot is expected from 
Germany as it holds the presidency of the Council from July to December 2020. Will the German leadership be able to bridge the most crucial gaps between contrasting visions of the EU's socioeconomic agenda? With Brexit unresolved and migration issues looming (among others), expectations may be too high. In any event, current events have opened a window of opportunity for Europeans to overcome old resistances and embrace investment in a socially fair ecological transition. Without a positive agenda, collective inaction may pave the way for a major reactionary backlash.

\section{References}

Andor, L. (2017) 'The Impact of Eurozone Governance on Welfare Stability'. In Vandenbroucke, F., Barnard, C. and De Bare, G. (eds) A European Social Union after the Crisis (Cambridge: Cambridge University Press), pp. 143-59.

Arpe, J., Milio, S. and Stuchlik, A. (2015) 'Social Policy Reforms in the EU: A Cross-national Comparison'. Social Inclusion Monitor Europe (SIM) - Reform Barometer. Available online at: https://www.bertelsmann-stiftung.de/fileadmin/files/user_upload/Study_EZ_SIM_Europe_ Reformbarometer_2015.pdf. Last accessed: 13 July 2018.

Blanchet, T., Chancel, L. and Gethin, A. (2019) 'Has the European Social Model Withstood the Rise in Inequalities?'. WID.world Issue Brief. 2019/2, Available online at: https://wid.world/ document/european-inequality-wil-summary-2019-en-pdf/. Last accessed: 15 July 2020.

Blyth, M. (2013) Austerity: The History of a Dangerous Idea (Oxford: Oxford University Press).

Braun, B. (2018) 'Central Banking and the Infrastructural Power of Finance: The Case of ECB Support for Repo and Securitization Markets'. Socio-Economic Review, doi: 10.1093/ser/ mwy008.

Copeland, P. and Daly, M. (2018) 'The European Semester and EU Social Policy'. JCMS, Vol. 56, No. 5, pp. 1001-18.

Council of the European Union. (2019) Explainer on the euro area budgetary instrument.

Crespy, A. (2016) Welfare Markets in Europe. The Democratic Challenge of European Integration (Basingstoke: Palgrave).

Crespy, A. and Menz, G. (2015) 'Introduction: The Pursuit of Social Europe in the Face of Crisis'. In Crespy, A. and Menz, G. (eds) Social Policy and the Eurocrisis. Quo Vadis Social Europe (Basingstoke: Palgrave), pp. 1-23.

Crespy, A. and Vanheuverzwijn, P. (2017) 'What 'Brussels' Means by Structural Reforms: Empty Signifier or Constructive Ambiguity?’ Comparative European Politics, Vol. 17, pp. 92-111.

Crouch, C. (2011) The Strange Non-death of Neo-liberalism (Cambridge: Polity Press).

Della Porta, D. (2015) Social Movements in Times of Austerity (Cambridge: Polity Press).

Ferrera, M. (2017) 'The European Social Union: A Missing but Necessary "Political Good"'. In Vandenbroucke, F., Barnard, C. and De Bare, G. (eds) A European Social Union after the Crisis (Cambridge: Cambridge University Press), pp. 47-67.

Font, N., Graziano, P. and Tsakatika, M. (2019) 'Varieties of Inclusionary Populism? SYRIZA, Podemos and the Five Star Movement'. Government and Opposition. https://doi.org/ 10.1017/gov.2019.17.

Goncalves Raposo, I. (2019) 'The June Eurogroup Meeting: Reflections on BICC'. Bruegel Blogpost. Available online at: https://www.bruegel.org/2019/06/the-june-eurogroup-meetingreflections-on-bicc. Last accessed: 28 February 2020.

Harmsen, R. (2005) 'L'Europe et les partis politiques nationaux: Les leçons d'un 'non-clivage'. Revue internationale de politique comparée, Vol. 12, No. 1, pp. 77-94. 
Hennette, S., Piketty, T., Sacriste, G. and Vauchez, A. (2017) 'Treaty on the Democratization of the Economic and Social Government of the European Union ("T-Dem")'. Available online at: http://tdem.eu/en/treaty/. Last accessed: 6 March 2020.

Kotroyannos, D., Tzagkarakis, S. I. and Pappas, I. (2018) 'South European Populism as a Consequence of the Multidimensional Crisis? The Cases of SYRIZA, PODEMOS and M5S'. Available online at: https://nbn-resolving.org/urn:nbn:de:0168-ssoar-59933-3. Last accessed: 15 July 2020.

Kriesi, H., Grande, E., Lachat, R., Dolezal, M., Bornschier, S. and Frey, T. (2008) West European Politics in the Age of Globalization (Cambridge: Cambridge University Press).

Mair, P. (2000) 'The Limited Impact of Europe on National Party Systems'. West European Politics, Vol. 23, No. 4, pp. 27-51.

Mair, P. (2013) 'Smaghi versus the Parties: Representative Government and Institutional Constraints'. In Schäffer, A. and Streeck, W. (eds) Politics in the Age of Austerity (Oxford: Polity), pp. 143-68.

Makszin, K., Medve-Bálint, G. and Bohle, D. (2020) 'North and South, East and West: Is it Possible to Bridge the Gap?' In Coman, R., Crespy, A. and Schmidt, V.A. (eds) Governance and Politics in the Post-crisis European Union (Cambridge: Cambridge University Press), pp. 335-57.

Matthijs, M. and MacNamara, K. (2015) 'The Euro Crisis' Theory Effect: Northern Saints, Southern Sinners, and the Demise of the Eurobond'. Journal of European Integration, Vol. 37, No. 2, pp. 229-45.

Mudde, C. and Kaltwasser, R. (2013) 'Exclusionary vs. Inclusionary Populism: Comparing Contemporary Europe and Latin America'. Government and Opposition, Vol. 48, No. 2, pp. 147-174.

Network/Counterbalance, B. (2019) 'Not Worth Celebrating Yet? The Investment Plan for Europe - A Critical Analysis of the Pilot Phase of the "Juncker Plan"'. Available online at: https:// bankwatch.org/wp-content/uploads/2019/09/EFSI-final.pdf. Last accessed: 29 February 2020.

Organization for Economic Cooperation and Development (2017) 'Understanding the Socio-economic Divide in Europe'. Background Report. Available online at: https://www. oecd.org/els/soc/cope-divide-europe-2017-background-report.pdf. Last accessed: 29 February 2020.

Papadopoulos, Y. and Piattoni, S. (2019) 'The European Semester: Democratic Weaknesses as Limits to Learning'. European Policy Analysis. doi: 10.1002/epa2.1060.

Pierret, L. (2019) 'The Political Use of the Term 'Moral Hazard': Evidence from Policymakers of the Eurozone'. Bruges Political Research Papers. 78, 78. Available online at: https://www. coleurope.eu/fr/research-paper/political-use-term-moral-hazard-evidence-policymakerseurozone. Last accessed: 15 July 2020.

Piketty, T. (2018) 'La couleur de la justice fiscale', Le Monde, 11 December 2018.

Sangiovanni, A. (2013) 'Solidarity in the European Union'. Oxford Journal of Legal Studies, Vol. 33, No. 2, pp. 213-41.

Schild, J. and Howarth, D. (2020) 'Fiscal Capacity Building in the Eurozone: Germany between the Hanseatic League Countries and France'. Paper Presented at the International Workshop, 'Furthering or Fighting Core State Power Integration? The Post-Maastricht Ambiguities of German EU Policy', Berlin, 24-25 June 2019.

Schmidt, V.A. (2014) 'Speaking to the Markets or to the People? A Discursive Institutionalist Analysis of the EU's Sovereign Debt Crisis'. British Journal of Politics and International Relations, Vol. 16, No. 1, pp. 188-209.

Schmidt, V.A. and Thatcher, M. (eds) (2013) Resilient Liberalism in Europe's Political Economy (Cambridge: Cambridge University Press). 
Schmitt-Beck, R. (2017) 'The 'Alternative für Deutschland in the Electorate': Between Single-issue and Right-wing Populist Party'. German Politics, Vol. 26,No. 1, pp. 124-48.

Seikel, D. and Truger, A. (2019) 'The Blocked Completion of the European Monetary Union'. Report. 52.

Spire, A. (2019) 'Reformuler la question sociale'. In Confavruex, J. (ed.) Le fond de l'air est jaune. Comprendre une révolte inédite (Paris: Seuil), pp. 91-8.

Sweeney, R. and Wilson, R. (2018) 'Cherishing All Equally 2019: Inequality in Europe and Ireland'. Available online at: https://www.feps-europe.eu/attachments/publications/ cherishing\%20all\%20equally\%202019.pdf. Last accessed: 15 July 2020.

Vandenbroucke, F., Barnard, C. and De Baere, G. (eds) (2016) A European Social Union after the Crisis (Cambridge: Cambridge University Press).

Vanheuverzwijn, P. and Crespy, A. (2018) 'Macro-economic Coordination and Elusive Ownership in the European Union'. Public Adminstration, Vol. 96, No. 3, pp. 578-93.

Zeitlin, J. and Vanhercke, B. (2017) 'Socializing the European Semester: EU Social and Economic Policy Co-Ordination in Crisis and Beyond'. Journal of European Public Policy, Vol. 25, No. 2, pp. 149-74. 